\title{
İşitme Yetersizliği Olan Öğrencilerin van Hiele Geometrik Düşünme Düzeyleri ${ }^{1}$
}

\section{Nurullah Şimşek ${ }^{2}$}

\section{Kenan Çağlıyan ${ }^{3}$}

\section{Type/Tür:}

Research/Araştırma

Received/Geliş Tarihi:

November 3/3 Kasim 2018

Accepted/Kabul Tarihi:

November 27/ 27 Kasim 2020

Page numbers/Sayfa No: 983-999

Corresponding Author/İletişimden

Sorumlu Yazar:

nurullah4006@gmail.com

\section{$\checkmark$ iThenticate}

This paper was checked for plagiarism using iThenticate during the preview process and before publication. / Bu çalışma ön inceleme sürecinde ve yayımlanmadan önce iThenticate yazılımı ile taranmıştır.

Copyright $@ 2017$ by Cumhuriyet University, Faculty of Education. All rights reserved.

\section{Öz}

İşitme kaybı hiç şüphesiz öğrencilerin öğrenme süreçlerini olumsuz yönde etkilemektedir. İşitme yetersizliği olan öğrencilerin mevcut öğrenme durumlarının tespit edilmesi onlara uygun öğrenme ortamları tasarlamak için önemlidir. Bu sebeple bu çalışmanı amacı, geometri öğretiminde önemli bir yeri olan van Hiele geometrik düşünme modeline göre işitme yetersizliği olan öğrencilerin geometrik kavramları ve bu kavramlar arasındaki ilişkileri ne düzeyde kavradıklarını tespit etmektir. $\mathrm{Bu}$ amaca yönelik olarak işitme yetersizliği olan $5,6,7$ ve 8 . sinıf öğrencilerinin geometrik düşünme düzeyleri resmedilerek bir betimleme yapılmıştır. Bu betimleme durum saptamasıyla gerçekleştirildiğinden bu çalışmanın modeli kesitsel taramadır. Çalışmanın örneklemini işitme engelliler ortaokullarına devam eden 126 öğrenci oluşturmuştur. Elde edilen bulgular çapraz tablolar üzerinden frekans ve yüzdelerle yorumlanarak sunulmuştur. Araştırma sonucunda işitme yetersizliği olan 126 öğrenciden 92'sinin (\%73) ön-tanıma düzeyinde olduğu tespit edilmiştir. Aynı öğrencilerden 31'i (\%24.6) görselleştirme düzeyinde yer almıştır. 126 öğrenciden sadece 3 (\%2.4) öğrenci analiz düzeyinde yer almıştır. Elde edilen bulgular ışığında, işitme yetersizliği olan ortaokul öğrencilerine yönelik gerçekleştirilecek geometri öğretiminde öğrencilerin mevcut öğrenme durumlarına uygun dil, örnek ve materyaller kullanılarak öğrenme ortamlarının tasarlanması önerilmiştir.

Anahtar Kelimeler: Matematik eğitimi, geometri, işitme yetersizliği olan öğrenciler, geometrik düşünme, van Hiele geometrik düşünme düzeyleri

\section{Suggested APA Citation/Önerilen APA Atıf Biçimi:}

Şimşek N., \& Çağlıyan, K. (2020). İşitme yetersizliği olan öğrencilerin van Hiele geometrik düşünme düzeyleri. Cumhuriyet International Journal of Education, 9(4), 983-999. http://dx.doi.org/10.30703/cije.478211 \footnotetext{
lisans tezinden üretilmiştir.

2 Dr. Öğr. Üyesi, Kırıkkale Üniversitesi, Eğitim Fakültesi, Kırıkkale/Türkiye Assist. Prof. Dr., Kırıkkale University, Faculty of Education, Kırıkkale/ Turkey e-mail: nurullah4006@gmail.com ORCID ID: orcid.org/0000-0003-2536-8285

3 Öğretmen, Atabey İmam Hatip Orta Okulu, Isparta/ Türkiye

Teacher, Atabey Imam Hatip Middle School, , Isparta / Turkey e-mail: kenan1453571@gmail.com ORCID ID: orcid.org/0000-0003-4455-2395
}

${ }^{1}$ Bu çalışma, Kenan Çağlıyan'ın Dr. Öğr. Üyesi Nurullah ŞiMŞEK'in danışmanlığında tamamlamış olduğu yüksek 


\title{
The van Hiele Geometric Thinking Levels of Hearing Impaired Students
}

\begin{abstract}
Hearing loss is undoubtedly affecting students' learning processes. It is important to identify the current learning situations of students with hearing impairment in order to design appropriate learning environments. Therefore, the purpose of this study is to determine how the hearing impaired students perceive geometry according to the van Hiele geometric thinking model which has an important place in geometry teaching. For this purpose, geometric thinking levels of middle school hearing impaired students are described. The model of this study is a cross-sectional survey. The sample of the study consisted of 126 students attending hearing impaired middle school in Ankara, Kirikkale, Niğde and Konya. The van Hiele geometric thinking levels test was used to determine the geometric thinking levels of hearing impaired students. Findings are presented by crosstable only by interpreting the frequencies and percentages. As a result of the research, 92 (73\%) of 126 hearing impaired students were at the pre-recognition level, $31(24.6 \%)$ at the visualization level and only $3(2.4 \%)$ students were at the level of analysis. In the light of the findings, it was proposed to design the learning environments by using language and materials appropriate to their current learning situations in the process of teaching geometry to hearing impaired students.
\end{abstract}

Keywords: Mathematics education, geometry, hearing impaired students, geometric thinking, the van Hiele Geometric Thinking model

\section{Giriş}

İşitme duyusu hem günlük yaşamda hem de eğitim ve öğretim sürecinde etkin bir şekilde kullanılan duyulardan bir tanesidir. İşitme kaybı, öğrencilerin dilsel, zihinsel, sosyal ve duyusal gelişimini olumsuz etkilemektedir (MEB, 2015). Bu sebeple işitme yetersizliği olan öğrenciler, işiten öğrencilerden farklılaşmaktadır. Bu farklılık literatürde sağır, işitme bozukluğu, işitme engeli, işitme kaybı ve işitme yetersizliği gibi kavramlarla ifade edilmektedir. Özel Eğitim Hizmetleri Yönetmenliği'nde "işitme yetersizliği olan birey" kavramı kullanılarak şu şekilde tanımlanmıştır: "İşitme duyarlılığının kısmen veya tamamen kaybından dolayı konuşmayı edinmede, dili kullanma ve iletişimde yaşadığı güçlükler nedeniyle özel eğitim ve destek eğitim hizmetine ihtiyacr olan birey." (MEB, 2012). Bu tanımdan anlaşıldığı üzere işitme yetersizliği, öğrencilerin öğrenme süreçlerini etkilemektedir (Tüfekçioğlu, 1998).

İşitme kaybı olan öğrenciler, öğrenme sürecinde bilgileri fark etmekte ve bu bilgiler arasında ilişkiler kurmakta işiten yaşıtlarına göre daha fazla zorluk yaşamaktadır (Marschark ve Hauser, 2012). Bu sebeple işitme kaybı olan öğrenciler, soyut bir ders olan matematikte işiten öğrencilere göre daha düşük başarı göstermektedir (Swanwick, Oddy ve Roper, 2005). Arnold'a (1996) göre bu düşük başarının iki nedeni vardır. Birincisi, İşitme kaybı olan öğrencilerdeki dilsel becerinin yaşıtlarına göre yeteri kadar gelişmemiş olmasıdır. İkincisi ise işitme kaybı olan öğrencilerin sosyal çevresinden kaynaklı olumsuzluklardır. Öğrencilerin öğrenmeleri için yeterli sürenin verilmemesi, uygun öğrenme ortamının oluşturulmaması ve yetenekli öğretmenlerle karşılaşmamaları gibi faktörler bu olumsuzluklara örnek olarak verilebilir. Araştırmacılar, bu olumsuzluklar ortadan kaldırıldığında işitme yetersizliği olan öğrencilerin de işiten öğrenciler gibi matematik öğrenebileceklerini ifade etmektedirler (Arnold, 1996; Marschark ve Hauser, 2012; Tanrıdiler, Uzuner ve Girgin, 2015). 
Matematik dersinin öğrenme alanlarından birisi olan geometrinin işitme kaybı olan öğrenciler için ayrı bir önemi bulunmaktadır. Geometri öğretiminin temel amaçları arasında öğrencilere uzamsal düşünme, geometriksel akıl yürütme, ispat yapma ve ilişki kurma gibi temel becerilerin kazandırılması yer almaktadır (MEB, 2010). Bu temel beceriler, işitme yetersizliği olan öğrencilerin toplum içerisinde bağımsız bir birey olarak hayatlarını sürdürebilmeleri için önemli olduğu düşünülmektedir. Çünkü günlük hayatta karşılaşılan eşyaların çoğu ya geometriksel bir cisimdir ya da geometriksel bir şekle sahiptir. Bu eşyaları etkin bir şekilde kullanmak için geometrik şekilleri, cisimleri ve bunlar arasındaki ilişkileri öğrenmek gerekmektedir. Ayrıca, günlük hayatta karşılaşılan bir problemi çizerek kâğıt üzerine aktarmak ve bir çözüm yolu bulmak için konumsal ve uzamsal farkındalığa gerek duyulmaktadır (Altun, 2014). $\mathrm{Bu}$ temel becerilerin geometri öğretimiyle kazandırılması hedeflenmektedir. Özellikle işitme yetersizliği olan bireylerin sosyal hayat içerisinde başarılı, bağımsız ve etkin olabilmeleri için geometri öğretimi onlar için ayrı bir öne sahip olduğu görülmektedir. $\mathrm{Bu}$ sebeple bu çalışma, işitme yetersizliği olan öğrencilerin geometri öğrenimleri bağlamında gerçekleştirilmiştir.

İşitme yetersizliği olan öğrenciler ile ilgili hem ulusal hem de uluslararası literatür incelendiğinde çalışmaların büyük bir çoğunluğunun okuma-yazma öğretimi ve dil becerisiyle ilgili olduğu görülmektedir (Tanrıdiler, 2013). Literatürde sınırlı sayıda çalışmanın matematik öğretimi hakkında gerçekleştirildiği ifade edilmektedir (Swanwick, Oddy ve Roper, 2005). Diğer taraftan işitme engelli öğrencilere geometri öğretimiyle alakalı ciddi problemlerin olduğu ifade edilmesine rağmen bu alanda gerçekleştirilmiş çalışma sayısının çok az olduğu rapor edilmektedir (Kemp, 2004). Bu sebeple literatürde var olan bu boşluğun doldurulmasına katkı sunmak amaciyla bu çalışmada işitme engelli öğrencilerin geometri öğrenimleri, van Hiele geometrik düşünme modeli perspektifinde incelenmiştir.

van Hiele geometrik düşünme modeli, öğrencilerin geometriyi nasıl kavradığını ve öğrencilerde geometrik düşünmenin hangi seviyede geliştiğini ortaya çıkarmaya yönelik bir modeldir (Baki, 2008). van Hiele geometrik düşünme modeli, 1959 yılında Hollandalı çift Dina van Hiele Geldof ve Pierre van Hiele tarafından yapılan çalışmalarla ortaya çıkmıştır. Bu model, sonraki yıllarda farklı ülkelerden eğitimcilerin ve politika geliştiricilerin ilgisini çekmeyi başarmıştır. van Hiele teorisi hakkında makaleler, tezler ve projeler hazırlanmıştır. Birçok ülkede geometri öğretim programları hazırlanırken bu model dikkate alınmıştır. van Hiele geometrik düşünme modeli öğrencilerin geometriyi nasıl kavradıklarını hiyerarşik bir yapıda açıklamaktadır (Usiskin, 1982). Modelde yer alan beş farklı düzeyle öğrencilerin geometrik kavramlara yönelik düşünme süreçleri ifade edilmektedir. van Hiele geometrik düşünme modelindeki düzeyler şu şekildedir: Düzey 0: ön-tanıma (Clements ve Battista, 1992), düzey 1: Görselleştirme, düzey 2: Analiz, düzey 3: İnformel/Basit Çıkarım, düzey 4: Çıkarım ve düzey 5: Sistematik Düşünme düzeyi. Düzeyler ardışık bir yapıda olduğundan dolayı bir düzeyin düşünme becerilerine sahip olunmadan bir sonraki düzeye geçilememektedir. Bir düzeyin düşünme becerisini kazanmadan bir üst düzeye çıkılmamaktadır. Düzeyler, yaştan bağımsız olarak öğrencilerin geometrik yaşantılarına göre oluşmaktadır. Örneğin, bir ilkokul öğrencisi ile bir lise öğrencisi aynı düzeyde yer alabilmektedir. Öğrencilerin düzeyler arasında ilerlemesi için bulunduğu 
düzeyde anlamlı öğrenme sürecini yaşaması, uygun dil ve örneklerle karşılaşması gerekmektedir (Duatepe-Paksu, 2016; van De Walle, Karp ve Bay-Williams, 2013).

Literatürde işitme yetersizliği olan öğrencilerin van Hiele geometrik düşünme düzeylerini inceleyen çok az sayıda çalışmaya ulaşılmıştır. Kemp (1990), ön test son test kontrol gruplu desenle sağır öğrencilerin geometri dersi öncesinde ve sonrasında van Hiele Geometri düşünmeye düzeylerini cinsiyet, okul türü, geometri ön bilgisi ve yazma becerisi değişkenlerine göre incelemiştir. Yıldırım (2009) ise bir dinamik geometri yazılımı yardımıyla hazırladı̆̆ı etkinliklerin öğrencilerin geometri başarılarına, van Hiele geometrik düşünme düzeylerine ve geometriye yönelik tutumlarına etkisini araştırmıştır. Görüldüğü üzere işitme engelli öğrenciler ile van Hiele geometrik düşünme modelinin birlikte ele alındığı çalışma sayısı sınırlıdır. Ortaokulda öğrenim gören işitme yetersizliği olan öğrencilerin van Hiele geometrik düşünme düzeylerinin tespit edilmesi ve farklı değişkenlere göre nasıl değiştiğinin ayrıntılı bir şekilde ortaya konulması literatürde var olan bir boşluktur. Bu sebeple bu çalışmanın amacı, geometri öğretimde uluslararası literatürde kabul görmüş van Hiele geometrik düşünme modeline göre işitme yetersizliği olan öğrencilerin geometriyi nasıl algıladıklarını ortaya çıkarmaktır. Bu bağlamda ortaokulda öğrenim gören işitme yetersizliği olan öğrencilerin van Hiele geometrik düşünme düzeyleri tespit edilmiş ve ayrıca geometrik düşünme düzeylerinin cinsiyete, sınıf düzeyine, mezun olunan ilkokul türüne, ailede işitme engelli başka bir birey olma durumuna, işitmeye yardımcı teknoloji kullanımına, destek eğitimi alma durumuna ve işaret dili seviyesine göre nasıl bir dağılım gösterdiği incelenmiştir.

Bu çalışma kapsamında aşağıdaki soruların cevapları aranmıştır:

1. İşitme engelli 5, 6, 7 ve 8 . sınıf öğrencilerinin van Hiele geometrik düşünme düzeyleri hangi seviyededir?

2. İşitme engelli 5, 6, 7 ve 8. sınıf öğrencilerinin van Hiele geometrik düşünme düzeyleri;

a) Cinsiyete,

b) Sinıf düzeyine,

c) Mezun olunan ilkokul türüne,

d) Ailede işitme engelli başka bir birey olma durumuna,

e) İşitmeye yardımcı teknoloji kullanımına,

f) Destek eğitimi alma durumuna ve

g) İşaret dili seviyesine göre nasıl dă̆ılım göstermektedir?

\section{Araştırma Modeli}

\section{Yöntem}

Çalışmanın amacına yönelik olarak işitme yetersizliği olan 5, 6, 7 ve 8. sınıf öğrencilerinin geometrik düşünme düzeyleri ile ilgili mevcut durum resmedilerek bir betimleme yapılmıştır. Bu betimleme anlık ve bir kez durum saptamasıyla gerçekleştirildiğinden bu çalışmanın modeli kesitsel taramadır. Kesitsel tarama araştırmalarında örneklem içerisindeki farklı özellikteki katılımcılara ilişkin var olan durum bir defa saptanarak bir betimleme yapilmaktadır. Bu modelde "neden" sorusundan çok "hangi düzeyde, hangi sıklıkta" gibi soruların cevapları araştırılmaktadır (Büyüköztürk, Çakmak-Kılıç, Akgün, Karadeniz ve Demirel, 2014; Karasar, 2006). 
Araştırmanın çalışma grubunu İç Anadolu Bölgesinde Ankara, Kırıkkale, Konya ve Niğde illerindeki MEB'e bağlı altı işitme engelliler ortaokullarında öğrenim görmekte olan 126 öğrenci oluşturmuştur. Bu öğrencilere ilişkin demografik özellikler Tablo 1'de sunulmuştur.

Tablo 1

Çalışma Gurubuna İlişkin Demografik Özellikler

\begin{tabular}{|c|c|c|c|c|c|c|c|c|}
\hline \multicolumn{2}{|c|}{ İşitme engelliler ortaokullar } & A & B & $\mathrm{C}$ & $\mathrm{D}$ & $\mathrm{E}$ & $\mathrm{F}$ & Toplam \\
\hline \multicolumn{2}{|l|}{ Öğrenci sayısı } & 13 & 13 & 33 & 46 & 12 & 9 & 126 \\
\hline \multirow{2}{*}{ Cinsiyet } & $\mathrm{K}_{12}$ & 6 & 8 & 18 & 21 & 4 & 7 & 64 \\
\hline & Erkek & 7 & 5 & 15 & 25 & 8 & 2 & 62 \\
\hline \multirow{2}{*}{ Destek eğitimi } & Aliyor & 11 & 7 & 23 & 21 & *... & 1 & 63 \\
\hline & Almiyor & 2 & 6 & 10 & 25 & 12 & 8 & 63 \\
\hline \multirow{2}{*}{$\begin{array}{l}\text { Ailesinde } \\
\text { kendisinden } \\
\text { başka işitme } \\
\text { engelli }\end{array}$} & Var & 2 & 11 & 7 & 30 & 4 & 5 & 60 \\
\hline & Yok & 11 & 2 & 26 & 16 & 8 & 4 & 66 \\
\hline \multirow{2}{*}{$\begin{array}{l}\text { İlkokulda eğitim } \\
\text { aldığı okul }\end{array}$} & Normal ilkokul & 1 & 4 & 3 & 4 & 3 & $\ldots$ & 15 \\
\hline & $\begin{array}{l}\text { İşitme engelliler } \\
\text { ilkokulu }\end{array}$ & 12 & 9 & 30 & 42 & 9 & 9 & 111 \\
\hline \multirow{4}{*}{ Sinif } & 5.Sinif & 3 & $\cdots$ & 9 & 9 & 1 & 2 & 24 \\
\hline & 6.Sinif & 3 & 1 & 8 & 11 & 1 & 1 & 25 \\
\hline & 7.Sinif & 3 & $\ldots$ & 13 & 12 & 7 & 1 & 36 \\
\hline & 8.Sinif & 4 & 12 & 3 & 14 & 3 & 5 & 41 \\
\hline \multirow{5}{*}{$\begin{array}{l}\text { İşaret dili bilme } \\
\text { seviyesi }\end{array}$} & Hiç & $\ldots$ & $\cdots$ & 4 & $\ldots$ & 2 & $\ldots$ & 6 \\
\hline & $\mathrm{Az}$ & $\ldots$ & $\ldots$ & 13 & 14 & 1 & $\ldots$ & 28 \\
\hline & Orta & 4 & 1 & 7 & 7 & 1 & 1 & 21 \\
\hline & İyi & 8 & 1 & 5 & 18 & 7 & 2 & 41 \\
\hline & Çok iyi & 1 & 11 & 4 & 7 & 1 & 6 & 30 \\
\hline \multirow{4}{*}{$\begin{array}{l}\text { İşitmeye yardımcı } \\
\text { teknoloji } \\
\text { kullanımı }\end{array}$} & Koklear implant & $\cdots$ & $\ldots$ & 15 & 1 & 4 & $\cdots$ & 20 \\
\hline & İşitme cihazı & 13 & 8 & 15 & 24 & 7 & 2 & 69 \\
\hline & Fm sistem & $\ldots$ & $\ldots$ & $\ldots$ & 16 & $\ldots$ & $\ldots$ & 16 \\
\hline & Hiçbiri & $\ldots$ & 5 & 3 & 5 & 1 & 7 & 21 \\
\hline
\end{tabular}

*... :Bu alana yönelik verinin olmadığını göstermektedir.

\section{Veri Toplama Araçları}

İşitme yetersizliği olan ortaokul öğrencilerin geometrik düşünme düzeylerini tespit etmek için van Hiele Geometrik Düşünme Düzeyleri Testi kullanılmıştır. Usiskin (1982) tarafından geliştirilen bu testin Duatepe (2000) tarafından Türkçeye uyarlaması ve geçerlik-güvenirlik çalışmaları yapılmıştır. Bu uyarlama çalışması kapsamında testin güvenirlik katsayısı 0.79 olarak hesaplanmıştır. van Hiele Geometrik Düşünme Düzeyleri Testi'nde toplam 25 soru bulunmaktadır. İlk beş soru düzey 1'i, 6-10. sorular düzey 2'yi, 11-15. sorular düzey 3'ü, 16-20. sorular düzey 4'ü ve 21-25. sorular düzey 5’i 
ölçmeye yönelik tasarlanmıştır. Bu araştırmanın çalışma grubunu ortaokul öğrencileri oluşturduğundan ve bu öğrenci grubunun yer alması beklenilen düzeyler dikkate alındığında (Bulut, Sünkür, Oral ve İlhan, 2012; Duatepe, 2004) van Hiele Geometrik Düşünme Düzeyleri Testi'nin ilk 15 sorusu kullanılmıştır.

Çalışma grubunda yer alan öğrencilerin cinsiyet, sınıf düzeyi, ailede işitme engelli birey olma durumu, işitmeye yardımcı teknoloji kullanımı, destek eğitimi alma durumu ve işaret dili seviyesi gibi bilgilerini almak için ayrıca demografik bilgi formu kullanılmıştır.

\section{Verilerin Toplanması ve Analizi}

Veri toplama sürecine başlamadan önce dört farklı ilde toplam altı okulda verilerin toplanması için Milli Eğitim Bakanlı̆̆ı'ndan izin alınmıştır. Veriler, 2015-2016 EğitimÖğretim yılının ikinci yarısında birinci yazar tarafından toplanmıştır. Birinci yazar, 2014-2017 yılları arasında işitme engelliler ortaokulunda matematik öğretmeni olarak görev yapmıştır. Aynı zamanda işaret dilini bilmektedir. Bu sebeple, van Hiele Geometrik Düşünme Düzeyleri Testi'nin uygulama sürecinde iletişim ve uygulama problemi yaşanmamıştır. Uygulama sürecinde ilk olarak, demografik bilgi formu dağıtılarak öğrencilerin doldurması istenmiştir. Daha sonra, test hakkında bilgilendirilme yapılarak testin uygulanmasına geçilmiştir. Öğgrencilerin testi tamamlamaları için 30 dakika süre verilmiştir.

van Hiele Geometrik Düşünme Düzeyleri Testi'nden elde edilen veriler doğrultusunda öğrencilerin düzeyleri belirlenirken Usiskin (1982) referans alınarak bir düzeydeki beş sorudan en az üçünün doğru yapılması kuralı benimsenmiştir. Örneğin, bir öğrenci ilk beş sorudan en az üçünü ve 6-10 soru grubundan da en az üçünü doğru cevaplamış fakat 11-15 soru gurubundan en az üç soruyu doğru cevaplayamamış ise bu öğrencinin düzey 2 'de olmasına karar verilmiştir. Başka bir öğrenci, ilk beş sorudan en az üçünü cevaplamış fakat 6-10 ve 11-15 soru gurupların her birisinden en az üç soruyu doğru cevaplayamamış ise bu öğrencinin düzey 1'de olmasına karar verilmiştir. Eğer bir öğrenci, 1-5 soru gurubunda en az üç soruyu doğru cevaplayamamış ise düzey 0’da ifade edilmiştir.

İşitme yetersizliği olan öğrencilerin van Hiele geometrik düşünme düzeylerinin demografik özelliklerine göre nasıl değişim gösterdiğini tespit etmek için analizler SPSS programında gerçekleştirilmiştir. Çalışma grubu 126 kişiden oluştuğu için normallik testinde Kolmogorov Smirnov testi kullanılmıştır (Büyüköztürk, 2008). $\mathrm{Bu}$ testten elde edilen sonuçlara göre veriler normal dağılım göstermediğinden kay-kare testi kullanılmıştır. Kay-kare testi sonucunda beklenen değeri 5'ten küçük olan gözenek sayısının toplam gözenek sayısının \%20'sini aştığından dolayı anlamlılık yorumlarının yapılması uygun değildir. Bu durumda üç seçenek söz konusudur. (I) Mantıklı olması durumunda beklenen değeri 5 'ten küçük olan satır ya da sütun düzeylerinde birleştirme yapılarak gözenekteki gözlem sayıları ve bunun sonucunda da beklenen değerler artırılmalıdır. (II) Gözenekler içerisinde 5'ten küçük beklenen değere sahip olan gözeneklerin, ilgili satır ya da sütun analiz dışı bırakılarak azaltma yoluna gidilmelidir (III) İlk iki maddedeki çözümlerin uygulanamaması durumunda çapraz tablolar üzerinden sadece frekans ve yüzdelerle yorumlar yapılmalıdır (Büyüköztürk, 2008, s.148). İlk iki maddede belirtilen çözüm yolları sonuç vermediği için üçüncü madde dikkate alınarak veriler analiz edilmiştir. 


\section{Bulgular}

$\mathrm{Bu}$ bölümde işitme yetersizliği olan öğrencilerin van Hiele geometrik düşünme düzeylerinin çeşitli değişkenlere göre nasıl bir dağılım gösterdiği frekans ve yüzdelerle sunulmuştur. İlk olarak, işitme yetersizliği olan öğrencilerin geometrik düşünme düzeylerinin cinsiyetlerine göre nasıl dağılım gösterdiği Tablo 2’ de gösterilmiştir.

Tablo 2

İşitme Yetersizliği Olan Öğrencilerin Cinsiyetlerine Göre Geometrik Düşünme Düzeyleri

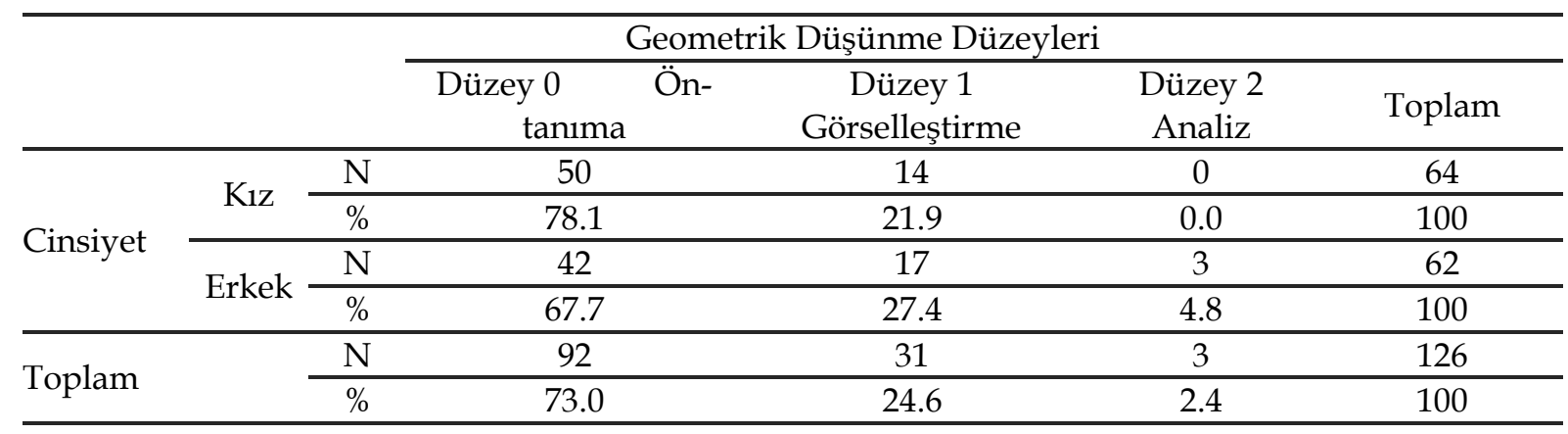

Tablo 2 incelendiğinde, k1z öğrencilerin \%78.1'i düzey 0’da yer aldı̆̆ 1 görülmektedir. Diğer taraftan k1z öğrencilerin \%21.9'u görselleştirme düzeyinde yer alırken analiz düzeyine atanabilen kız öğrenci olmamıştır. Erkek öğrencilerin \%67.7'si düzey 0 'a atanmıştır. Diğer taraftan erkek öğrencilerin \%27.4'ü görselleştirme düzeyinde yer alırken \%4.8'i analiz düzeyinde yer almaktadır. İşitme yetersizliği olan öğrencilerin van Hiele geometrik düşünme düzeylerinin sınıf düzeyine göre nasıl dağılım gösterdiği Tablo 3'te sunulmuştur.

Tablo 3

İsitme Yetersizliği Olan Öğrencilerin Sınf Düzeylerine Göre Geometrik Düşünme Düzeyleri

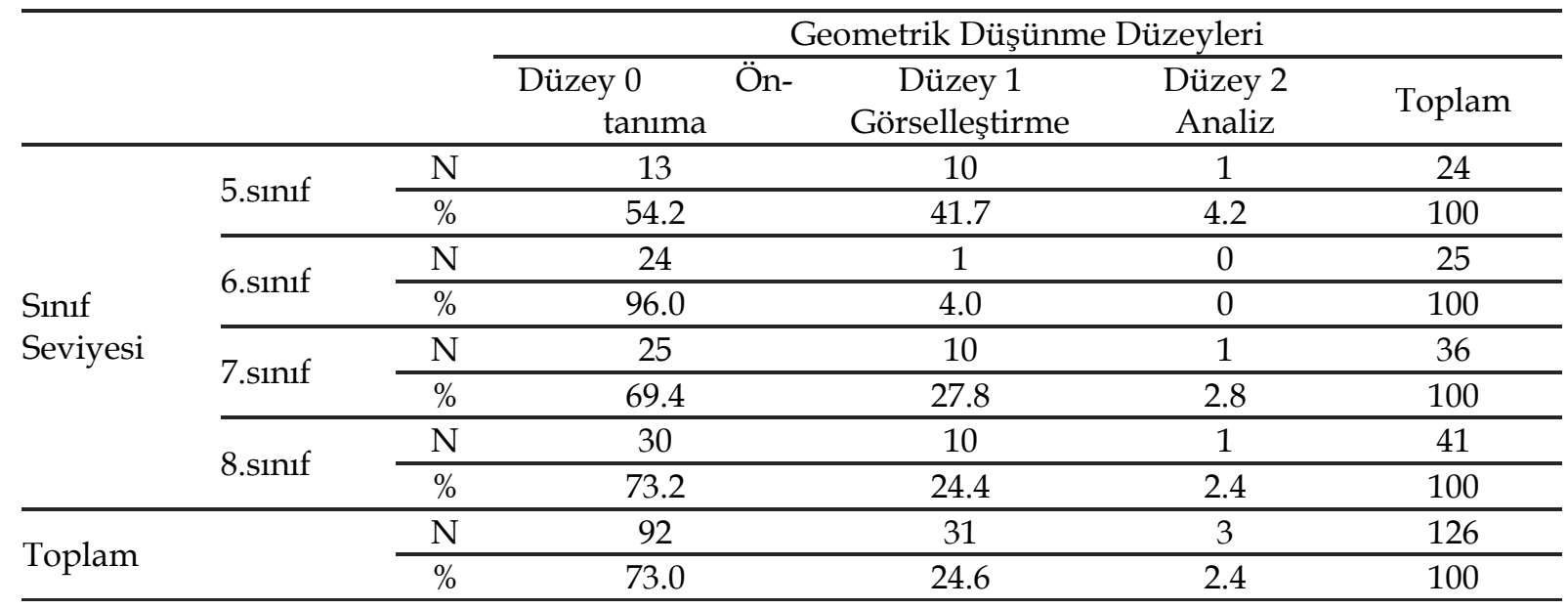

Tablo 3 incelendiğinde, 5. sinıfta öğrenim gören öğrencilerin \%54.2'si düzey 0'a atandığ1 görülmektedir. Diğer taraftan 5. sınıf öğrencilerin \%41.7'si görselleştirme düzeyinde ve \%4.2'si analiz düzeyinde yer almaktadır. 6. sinıfta öğrenim gören öğrencilerin \%96'sı düzey 0'da yer alırken, \%4'ü görselleștirme düzeyinde yer almaktadır. Dikkat çeken diğer bir bulgu ise analiz düzeyinde 6. sinıf öğrencisinin 
olmamasıdır. 7. sınıfta öğrenim gören öğrencilerin \%69.4'ü düzey 0'a atanmıştır. Aynı öğrencilerin \%27.8'i görselleştirme düzeyinde ve \%2.8'i analiz düzeyinde yer almaktadır. 8.sınıfta öğrenim gören öğrencilerin \%73.2'si düzey 0 'da yer alırken \%24.4'ü görselleştirme düzeyinde ve \%2.4’ü analiz düzeyinde yer almaktadır. İşitme yetersizliği olan öğrencilerin van Hiele geometrik düşünme düzeylerinin mezun oldukları ilkokul türüne göre nasıl dağılım gösterdiği Tablo 4'te sunulmuştur.

Tablo 4'de görüldüğü gibi ilkokul öğrenimini normal ilkokullarda tamamlamış öğrencilerin \%46.7'si düzey 0'a atanırken \%53.3'ü görselleştirme düzeyinde yer almaktadır. Normal ilkokullardan mezun olmuş öğrencilerden analiz düzeyine atanabilen öğrenci olmamıştır. İlkokul öğrenimini işitme engelliler ilkokullarında tamamlamış olan öğrencilerin \%76.6'sı düzey 0'a atanmıştır. Bu öğrencilerin \%20.7'si görselleştirme düzeyinde ve \% 2.7'si analiz düzeyinde yer almaktadır. İşitme yetersizliği olan öğrencilerin van Hiele geometrik düşünme düzeylerinin ailede başka bir işitme engelli birey olma durumuna göre nasıl dağılım gösterdiği Tablo 5 'te sunulmuştur.

Tablo 4

İşitme Yetersizliği Olan Öğrencilerin Mezun Olduklarn İlkokul Türüne Göre Geometrik Düşünme Düzeyleri

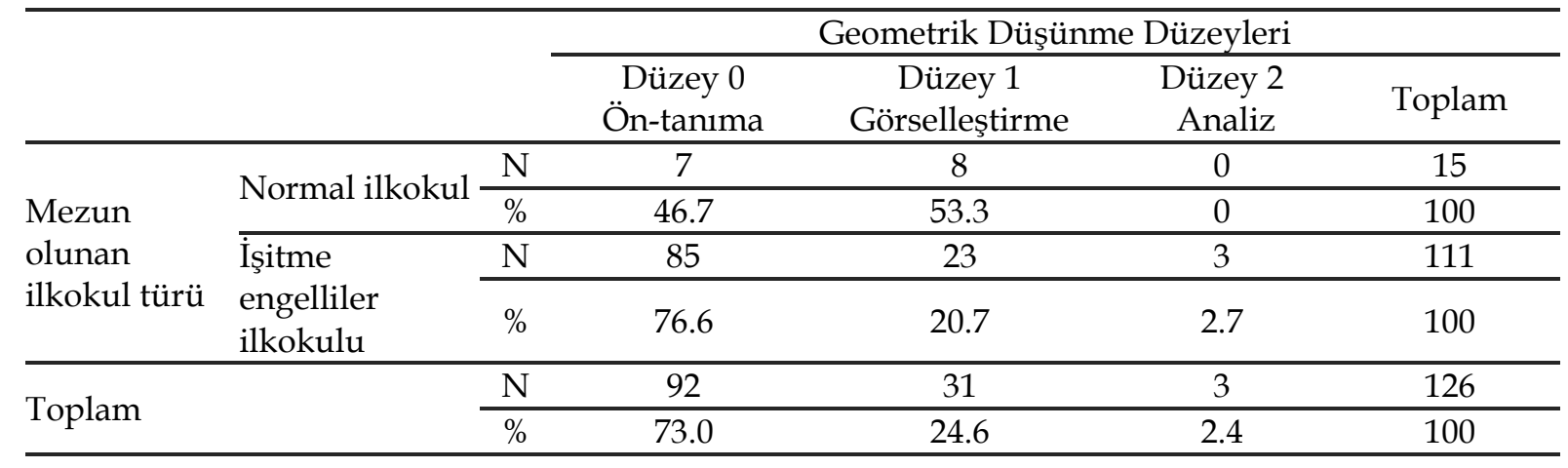

Tablo 5

İşitme Yetersizliği Olan Öğrencilerin Ailelerinde İşitme Engelli Birey Olma Durumuna Göre Geometrik Düşünme Düzeyleri

\begin{tabular}{|c|c|c|c|c|c|c|}
\hline & & & \multicolumn{4}{|c|}{ Geometrik Düşünme Düzeyleri } \\
\hline & & & $\begin{array}{r}\text { Düzey } 0 \\
\text { tanıma } \\
\end{array}$ & $\begin{array}{cc}\text { Ön- } & \text { Düzey 1 } \\
& \text { Görselleştirme } \\
\end{array}$ & $\begin{array}{c}\text { Düzey } 2 \\
\text { Analiz }\end{array}$ & Toplam \\
\hline \multirow{4}{*}{$\begin{array}{l}\text { Ailede işitme } \\
\text { engelli birey olma } \\
\text { durumu }\end{array}$} & \multirow{2}{*}{ Var } & $\mathrm{N}$ & 45 & 14 & 1 & 60 \\
\hline & & $\%$ & 75.0 & 23.3 & 1.7 & 100 \\
\hline & \multirow{2}{*}{ Yok } & $\mathrm{N}$ & 47 & 17 & 2 & 66 \\
\hline & & $\%$ & 71.2 & 25.8 & 3.0 & 100 \\
\hline \multirow{2}{*}{ Toplam } & & $\mathrm{N}$ & 92 & 31 & 3 & 126 \\
\hline & & $\%$ & 73.0 & 24.6 & 2.4 & 100 \\
\hline
\end{tabular}

Tablo 5 incelendiğinde, ailesinde kendisinden başka işitme engelli olduğunu belirten öğrencilerin \%75'i düzey 0'a atand1ğı görülmektedir. Bu öğrencilerin \%23.3'ü görselleştirme düzeyinde ve \%1.7'si analiz düzeyinde yer almaktadır. Ailesinde kendisinden başka işitme engelli olmadığını belirten öğrencilerin \%71.2'si düzey 0'da 
yer almıştır. Aynı öğrencilerin \%25.8'i görselleştirme düzeyinde ve \%3'ü analiz düzeyinde yer almaktadır. İşitme yetersizliği olan öğrencilerin van Hiele geometrik düşünme düzeylerinin işitmeye yardımcı teknoloji kullanımına göre nasıl dağılım gösterdiği Tablo 6'da sunulmuştur.

Tablo 6

İşitme Yetersizliği Olan Öğrencilerin İşitmeye Yardımo Teknoloji Kullanımlarına Göre Geometrik Düşünme Düzeyleri

\begin{tabular}{|c|c|c|c|c|c|c|}
\hline & & & \multicolumn{4}{|c|}{ Geometrik Düşünme Düzeyleri } \\
\hline & & & $\begin{array}{r}\text { Düzey } 0 \\
\text { tanıma }\end{array}$ & $\begin{array}{cc}\text { Ön- } & \text { Düzey } 1 \\
\text { Görselleştirme }\end{array}$ & $\begin{array}{l}\text { Düzey } 2 \\
\text { Analiz }\end{array}$ & Toplam \\
\hline \multirow{8}{*}{$\begin{array}{l}\text { İşitmeye } \\
\text { yardımc1 } \\
\text { teknolojiler }\end{array}$} & \multirow{2}{*}{ Koklear implant } & $\mathrm{N}$ & 14 & 6 & 0 & 20 \\
\hline & & $\%$ & 70 & 30 & 0 & 100 \\
\hline & \multirow{2}{*}{ İşitme cihazı } & $\mathrm{N}$ & 51 & 16 & 2 & 69 \\
\hline & & $\%$ & 73.9 & 23.2 & 2.9 & 100 \\
\hline & \multirow{2}{*}{ FM sistemler } & $\mathrm{N}$ & 11 & 4 & 1 & 16 \\
\hline & & $\%$ & 68.8 & 25.0 & 6.3 & 100 \\
\hline & \multirow{2}{*}{ Hiçbiri } & $\mathrm{N}$ & 16 & 5 & 0 & 21 \\
\hline & & $\%$ & 76.2 & 23.8 & 0 & 100 \\
\hline \multirow{2}{*}{ Toplam } & & $\mathrm{N}$ & 92 & 31 & 3 & 126 \\
\hline & & $\%$ & 73.0 & 24.6 & 2.4 & 100 \\
\hline
\end{tabular}

Tablo 6 ‘da görüldüğü gibi Koklear implant kullanan öğrencilerin \% 70’i düzey 0 'a atanmıştır. Aynı öğrencilerin \%30'u görselleştirme düzeyinde yer alırken analiz düzeyinde Koklear implant kullanan öğrencilerin hiçbiri yer alamamıştır. Diğer taraftan İşitme cihazı kullanan öğrencilerin \%73.9'u düzey 0'a atanırken \%23.2'si görselleştirme düzeyinde ve $\% 2.9^{\prime} \mathrm{u}$ analiz düzeyinde yer almaktadır. FM sistemler kullanan öğrencilerin \%68.8'i ise herhangi bir düzey $0^{\prime}$ a atanmıştır. Bu öğrencilerin \%25'i görselleştirme düzeyinde ve \%6.3'ü analiz düzeyinde yer almaktadır. İsitmeye yardımcı olarak herhangi bir cihaz kullanmayan öğrencilerin \%76.2'si düzey 0 'da ve \%23.8'i görselleştirme düzeyinde yer almaktadır. İşitmeye yardımcı olarak herhangi bir cihaz kullanmayan öğrencilerden analiz düzeyine atanabilen öğrenci bulunmamaktadır. İşitme yetersizliği olan öğrencilerin van Hiele geometrik düşünme düzeylerinin destek eğitimi alma durumuna göre nasıl dağılım gösterdiği Tablo 7' de sunulmuştur.

Tablo 7

İşitme Yetersizliği Olan Öğrencilerin Destek Eğitimi Alma Durumlarna Göre Geometrik Düşünme Düzeyleri

\begin{tabular}{|c|c|c|c|c|c|c|c|}
\hline & & & \multicolumn{5}{|c|}{ Geometrik Düşünme Düzeyleri } \\
\hline & & & $\begin{array}{l}\text { Düzey } 0 \\
\text { tanıma }\end{array}$ & Ön- & $\begin{array}{c}\text { Düzey } 1 \\
\text { Görselleştirme }\end{array}$ & $\begin{array}{c}\text { Düzey } 2 \\
\text { Analiz }\end{array}$ & Toplam \\
\hline \multirow{4}{*}{$\begin{array}{l}\text { Destek eğitimi } \\
\text { alma durumu }\end{array}$} & \multirow{2}{*}{ Evet } & $\mathrm{N}$ & 47 & & 15 & 1 & 63 \\
\hline & & $\%$ & 74.6 & & 23.8 & 1.6 & 100 \\
\hline & \multirow{2}{*}{ Hayır } & $\mathrm{N}$ & 45 & & 16 & 2 & 63 \\
\hline & & $\%$ & 71.4 & & 25.4 & 3.2 & 100 \\
\hline \multirow{2}{*}{ Toplam } & & $\mathrm{N}$ & 92 & & 31 & 3 & 126 \\
\hline & & $\%$ & 73.0 & & 24.6 & 2.4 & 100 \\
\hline
\end{tabular}


Tablo 7 incelendiğinde, destek eğitimi alan öğrencilerin \% 74.6'sının ön-tanıma düzeyinde, \%23.8'inin görselleştirme düzeyinde olduğu ve \%1.6'sının analiz düzeyinde yer aldığ1 görülmektedir. Destek eğitimi almadığını belirten öğrencilerin \%71.4'ü öntanıma düzeyinde, \%25.4'ü görselleştirme düzeyinde ve \%3.2'si analiz düzeyinde yer almaktadır. İşitme yetersizliği olan öğrencilerin van Hiele geometrik düşünme düzeylerinin işaret dili seviyelerine göre nasıl dağılım gösterdiği Tablo 8'de sunulmuştur.

Tablo 8

İşitme Yetersizliği Olan Öğrencilerin İşaret Dili Seviyelerine Göre Geometrik Düşünme Düzeyleri

\begin{tabular}{|c|c|c|c|c|c|c|}
\hline & & & \multicolumn{4}{|c|}{ Geometrik Düşünme Düzeyleri } \\
\hline & & & $\begin{array}{cc}\text { Düzey } 0 & \text { Ön- } \\
\text { tanıma } & \\
\end{array}$ & $\begin{array}{c}\text { Düzey } 1 \\
\text { Görselleştirme }\end{array}$ & $\begin{array}{l}\text { Düzey } 2 \\
\text { Analiz }\end{array}$ & Toplam \\
\hline \multirow{10}{*}{$\begin{array}{l}\text { İşaret dili } \\
\text { seviyesi }\end{array}$} & \multirow{2}{*}{ Hiç bilmiyor } & $\mathrm{N}$ & 6 & 0 & 0 & 6 \\
\hline & & $\%$ & 100 & 0.0 & 0.0 & 100 \\
\hline & \multirow{2}{*}{ Biraz } & $\mathrm{N}$ & 23 & 5 & 0 & 28 \\
\hline & & $\%$ & 82.1 & 17.9 & 0.0 & 10 \\
\hline & \multirow{2}{*}{ Orta } & $\mathrm{N}$ & 12 & 8 & 1 & 21 \\
\hline & & $\%$ & 57.1 & 38.1 & 4.8 & 100 \\
\hline & \multirow{2}{*}{ İyi } & $\mathrm{N}$ & 27 & 12 & 2 & 41 \\
\hline & & $\%$ & 65.9 & 29.3 & 4.9 & 100 \\
\hline & \multirow{2}{*}{ Çok iyi biliyor } & $\mathrm{N}$ & 24 & 6 & 0 & 30 \\
\hline & & $\%$ & 80.0 & 20.0 & 0.0 & 100 \\
\hline \multirow{2}{*}{ Toplam } & & $\mathrm{N}$ & 92 & 31 & 3 & 126 \\
\hline & & $\%$ & 73.0 & 24.6 & 2.4 & 100 \\
\hline
\end{tabular}

Tablo 8'de görüldüğü gibi işaret dilini hiç bilmediğini söyleyen öğrencilerin \%100'ü düzey 0'a atanmıştır. Başka bir ifadeyle İşaret dilini hiç bilmediğini söyleyen öğrencilerden görselleştirme düzeyine ve analiz düzeyine ulaşan öğrenci yoktur. İşaret dilini biraz bildiğini söyleyen öğrencilerin \%82.1'i düzey 0'a atanırken \%17.9'u görselleştirme düzeyinde yer almaktadır. İşaret dilini biraz bildiğini söyleyen öğrencilerinden analiz düzeyine atanabilen öğrenci bulunmamaktadır. İşaret dilini orta seviyede bildiğini söyleyen öğrencilerin \%57.1'i düzey $0^{\prime}$ a atanmıştır. Bu öğrencilerin \%38.1'i görselleştirme düzeyinde ve \%4.8'i analiz düzeyinde yer almaktadır. İşaret dilini iyi seviyede bildiğini söyleyen öğrencilerin \%65.9'u ön-tanıma düzeyine, \%29.3'ü görselleştirme düzeyinde ve $\% 4.9^{\prime} \mathrm{u}$ analiz düzeyinde yer almaktadır. Diğer taraftan İşaret dilini çok iyi seviyede bildiğini söyleyen öğrencilerin \%80'i ön-tanıma düzeyinde yer alırken \%20'si görselleştirme düzeyinde yer almaktadır. İşaret dilini çok iyi bildiğini söyleyen öğrencilerden analiz düzeyinde ulaşabilen öğrenci bulunmamaktadır.

\section{Tartışma, Sonuç ve Öneriler}

$\mathrm{Bu}$ çalışmada işitme yetersizliği olan ortaokul öğrencilerin geometriyi nasıl kavradıklarını ortaya çıkarmak amacıyla van Hiele geometrik düşünme düzeyleri araştırılmıştır. Dört farklı ilde bulunan altı işitme engelliler ortaokulunda öğrenimine devam eden 126 öğrencinin katıldığ düzeyleri yedi farklı değişken açısından incelenmiştir. Süreksiz değişkenlere ilişkin 
bulgular çapraz tablolar ile frekans ve yüzdelerle sunulmuştur. Araştırma sonucunda işitme yetersizliği olan 126 öğrenciden 92'si (\%73) ön-tanıma düzeyinde olduğu tespit edilmiştir. Aynı öğrencilerden 31'i (\% 24.6) birinci düzey olan görselleştirme düzeyinde yer almıştır. 126 öğrenciden sadece 3 (\%2.4) öğrenci ikinci düzey olan analiz düzeyinde yer almiştır.

İşitme yetersizliği olan ortaokul öğrencilerin geometrik düşünme düzeylerinin cinsiyete göre dağılımları incelendiğinde, aralarında çok bir fark olmamakla birlikte erkek öğrenciler lehine bir durum ortaya çıkmıştır. Hem kız hem de erkek öğrencilerin büyük bir çoğunluğu ön-tanıma düzeyinde bulunmaktadır. Kız öğrencilerin \%78.1'i, erkek öğrencilerin \%67.7'si ön-tanıma düzeyinde yer almıştır. Bir üst düzey olan Görselleştirme düzeyine ise k1z öğrencilerin \%21.9'u, erkek öğrencilerin \%27.4'ü atanmıştır. Analiz düzeyinde kız öğrenci bulunmazken erkek öğrencilerden sadece 3 öğrenci analiz düzeyinde yer almıştır. Diğer taraftan Fidan ve Türnüklü (2010) tarafından normal işiten ortaokul öğrencileriyle yapılan çalışmada kız öğrencilerin geometrik düşünme düzeyleri erkek öğrencilerin düşünme düzeylerinden daha yüksek olduğu tespit edilmiştir. Bu bağlamda işitme engelli öğrencilerin geometrik düşünme düzeylerinin cinsiyete göre dağılımları ile normal işiten öğrencilerin geometrik düşünme düzeylerinin cinsiyete göre dağılımlarının farklılık gösterdiği söylenebilir.

İşitme yetersizliği olan 126 ortaokul öğrencisinin geometrik düşünme düzeylerinin sınıf seviyelerine göre dağılımları incelendiğinde, analiz düzeyinde yer alan öğrenci sayısının çok az olduğu görülmektedir. Altıncı sınıflardan hiçbir öğrenci analiz düzeyinde yer almazken beşinci, yedinci ve sekizinci sınıf öğrencilerinden sadece birer öğrenci analiz düzeyinde yer almıştır. Diğer taraftan görselleştirme düzeyinde ise altıncı sınıflardan sadece bir öğrenci yer alırken beşinci, yedinci ve sekizinci sınıf öğrencilerinden 10'ar öğrenci görselleştirme düzeyinde yer almıştır. Bütün sınıf seviyelerinde öğrencilerin büyük bir kısmı ön-tanıma düzeyinde yer almıştır. Beşinci sinıfta öğrenim gören 24 öğrenciden 13’ü (\%54.2) ön-tanıma düzeyinde iken 10 (\%27.8) öğrencinin görselleştirme düzeyinde olduğu tespit edilmiştir. Beşinci sınıf öğrencilerinden sadece biri analiz düzeyinde yer almıştır. Fidan ve Türnüklü (2010) tarafından normal işiten 5. Sınıf öğrencileriyle yapılan çalışmada ise öğrencilerin $\% 47.9^{\prime}$ u görselleştirme düzeyinde, \%29.3'ü analiz düzeyinde, \%16.7'si basit çıkarım düzeyinde ve \%6.1'i çıkarım düzeyinde olduğu rapor edilmiştir. Diğer taraftan bu çalışmaya sekizinci sınıfta öğrenimine devam eden 41 öğrenci katılmıştır. Bu öğrencilerden 30'u (\%73.2) ön-tanıma düzeyinde yer alırken 10 (\%24.4) öğrenci görselleştirme düzeyinde yer almıştır. Bu öğrencilerden sadece biri analiz düzeyinde yer almıştır. Yıldırım (2009) tarafından sekizinci sınıfta öğrenim gören 25 işitme yetersizliği olan öğrencinin verilen eğitim öncesi ve sonrası van Hiele geometrik düşünme düzeyleri karşılaştırılmıştır. Yapılan çalışma kapsamında eğitim öncesinde 8 . sinıf öğrencilerinden 14 'ü (\%56) görselleştirme düzeyimde yer alırken 11'i (\%44) analiz düzeyinde yer almıştır. Bulut, Sünkür, Oral ve İlhan (2012) tarafından 8. Sinıfa devam eden normal işiten 308 öğrencinin geometrik düşünme düzeyleri incelemiştir. Bu çalışmada öğrencilerin \%11'i ön-tanıma, \%49.7'si görselleştirme, \%26.3'ü analiz, \%13'ü basit çıkarım düzeyinde olduğu tespit edilmiştir.

Normal işiten öğrencilerin sınıf seviyelerine göre van Hiele geometrik düşünme düzeylerinin hangilerinde olması gerektiğine ilişkin yapılan araştırmalar neticesinde bazı görüşler ortaya konmuştur. Amerika Ulusal Matematik Öğretmenleri 
Konseyi'ne göre öğrencilerin üçüncü sınıfa kadar görselleştirme düzeyinde, üçüncü sınıftan altıncı sınıfa kadar analiz düzeyinde ve altıncı sınıftan dokuzuncu sinıfa kadar basit çıkarım düzeyinde olması beklenmektedir (NCTM, 2000). Benzer şekilde van De Walle ve arkadaşları (2012), sekizinci sınıfa kadar öğrencilerin görselleştirme, analiz ve basit çıkarım düzeylerinde olabileceklerini belirtmişlerdir. Diğer taraftan Baykul (2009), altıncı sınıfa kadar öğrencilerin görselleştirme ve analiz düzeylerinde altıncı sınıftan dokuzuncu sınıfa kadar ise basit çıkarım düzeyinde olabileceklerini belirtmiştir. Clements ve Battista (1992) ise okul öncesi öğrencilerinin geometrik düşünme becerilerinin görselleştirme düzeyinden önce ön-tanıma düzeyinde olabileceğini ifade etmiştir. Literatürde normal işiten öğrencilere yönelik beklenilen bu geometrik düşünme düzeyleri ile bu çalışma kapsamında elde edilen sonuçlar kıyaslandığında işitme yetersizliği olan ortaokul öğrencilerin geometrik düşünme düzeylerinin normal öğrencilere göre düşük seviyelerde olduğu söylenebilir. Örneklemde yer alan ortaokul öğrencilerinin \%73’ü ön-tanıma düzeyinde olduğu tespit edilmiştir. Buna göre bu öğrencilerin geometrik düşünme düzeyleri okul öncesi öğrencilerinin olması beklenilen düzeyde oldukları söylenebilir. Diğer taraftan öğrencilerin \%24.6's1 görselleştirme düzeyinde ve \%2.4'ününde analiz düzeyinde olduğu göz önüne alındığında yine bu öğrencilerin de ilkokul öğrencilerin olması beklenilen düzeyde oldukları söylenebilir. Normal işiten ortaokul öğrencilerinin basit çıkarım düzeyinde olması beklenilirken bu çalışmada yer alan işitme yetersizliği olan ortaokul öğrencilerinden hiçbiri basit çıkarım düzeyinde yer alamamıştır.

İşitme yetersizliği olan ortaokul öğrencilerin van Hiele geometrik düşünme düzeylerinin beklenilen seviyeden düşük çıkmasının gerisinde birçok farklı sebeplerin olduğu düşünülmektedir. İşitme yetersizliği olan öğrencilerde uzamsal fikir ve düşüncelerin istenilen seviyede olmaması sadece onlardaki işitme kaybına bağlı olduğunun düşünülmesi doğru olmayacaktır. Amerika Ulusal Matematik Öğretmenleri Konseyi Standartlarında her öğrenciye yeteri kadar süre verilip uygun şartlar sağlandığı takdirde öğrencilerdeki geometriksel fikir ve anlayışların gelişebileceği ifade edilmektedir (NCTM, 2000). Başka bir ifadeyle işitme yetersizliği olan öğrenciler için geometri dersleri uygun öğrenme ortamlarında ve yeterli süre içersinde işlenildiği takdirde bu öğrencilerin geometriye ilişkin kavrayışları ve akıl yürütme becerilerinin gelişebileceği söylenebilir. Bu çalışma kapsamında ulaşılan sonuçlara göre işitme yetersizliği olan ortaokul öğrencilerinin büyük bir çoğunluğu ön-tanıma düzeyine yer almıştır. Ön-tanıma düzeyinde yer alan öğrencilerin geometrik düşünme yapılara genel olarak şu şekilde ifade edilmektedir. Ön-tanıma düzeyindeki öğrenciler, eğrisel çizgilerle oluşan şekillerle doğrusal çizgilerle oluşan şekilleri birbirinden ayırabilmektedir. Örneğin, bu öğrenciler bir çember ile bir dikdörtgeni ayırabilirken dikdörtgen ile üçgen arasında ayrımı yapamamaktadır. Bu düzeydeki öğrenciler geometrik şekilleri algılamalarına rağmen şekillerin sadece birkaç görsel özelliğine dikkat etmektedir. Bu sebeple bu düzeydeki öğrenciler yaygın olarak kullanılan bazı şekilleri tanımlayamamaktadır. Benzer şekilde öğrenciler, geometrik özellikler bakımından aynı sınıfta olan şekilleri birbirinden ayıramamaktadır. Çünkü bu öğrenciler zihinlerinde gerekli görsel imajları oluşturmakta zorlanmaktadır (Clements ve Battista, 1992). Bu çalışmadan elde edilen bulgular 1şı̆̆ında, işitme yetersizliği olan öğrencilere yönelik gerçekleştirilecek geometri öğretimlerinde öğrencilerin bu mevcut 
düşünme yapıları dikkate alınarak bu düşünme düzeylerine uygun dil, materyal ve örneklerle öğrenme ortamı tasarımının yapılması tavsiye edilmektedir.

\section{Kaynakça}

Arnold, P. (1996). Deaf children and mathematics. Croatian Review of Rehabilitation Research, 32(1), 65-72.

Altun, M. (2014). Ortaokullarda (5, 6, 7 ve 8. stmıflarda) matematik öğretimi. Bursa: Alfa Akademi.

Baykul, Y. (2009). İlköğretimde matematik öğretimim 6-8.sınıflar. Ankara: Pegem Akademi.

Baki, A. (2008). Kuramdan uygulamaya matematik eğitimi. Ankara: Harf Eğitim Yayıncılık.

Bulut, İ., Sünkür, O. M., Oral, B. ve İlhan M. (2012). 8. sınıf öğrencilerinin geometrik düşünme düzeyleri ile zekâ alanları arasındaki ilişkinin incelenmesi. Elektronik Sosyal Bilimler Dergisi, 11(41), 161-173.

Büyüköztürk, Ş. (2008). Sosyal bilimler için veri analizi el kitabı. Ankara: Pegem Akademi.

Büyüköztürk, Ş., Çakmak, E., Akgün, Ö., Karadeniz, Ş., ve Demirel, E. (2014). Bilimsel araştırma yöntemleri. Ankara: Pegem Akademi.

Clements, D. H., and Battista, M. T. (1992). Geometry and spatial reasoning. In D. A. Grouws (Ed.), Handbook of research on mathematics teaching and learning (pp. 420464). New York: Macmillan.

Duatepe, A. (2000). An investigation on the relationship between van Hiele geometric level of thinking and demographic variables for preservice elemantary school teachers.

(Yayımlanmamış Yüksek lisans Tezi). Orta Doğu Teknik Üniversitesi, Fen Bilimleri Enstitüsü, Ankara.

Duatepe, A. (2004). Drama temelli öğretimin yedinci sını öğrencilerinin geometri başarısına, van Hiele geometrik düşünme düzeylerine, matematiğe ve geometriye karşı tutumlarına etkisi. (Yayımlanmamış Doktora Tezi). Orta Doğu Teknik Üniversitesi, Fen Bilimleri Enstitüsü, Ankara.

Duatepe-Paksu, A. (2016). van Hiele geometrik düşünme düzeyleri. E. Bingölbali, S. Arslan ve İ. Ö. Zembat (Eds.) Matematik eğitiminde teoriler içinde, (s.265-275), Ankara: Pegem Akademi.

Fidan, Y. ve Türnüklü, E. (2010). İlköğretim 5. sınıf öğrencilerinin geometrik düşünme düzeylerinin bazı değişkenler açısından incelenmesi. Pamukkale Üniversitesi Ĕ̆itim Fakültesi Dergisi, 27, 185-197.

Karasar, N. (2006). Bilimsel araştırma yöntemi. Ankara: Nobel Yayın Dağıtım.

Kemp, V. (1990). The van Hiele levels of geometric thought and achievement in Euclidean geometry among deaf undergraduate students. (Doctoral dissertation) George Mason University.

Kemp, V. (2004). The van Hiele levels of geometric thought and achievement among deaf undergraduate students. In D. Martin (Ed.), Advances in cognition, education, and deafness. Washington, DC: Gallaudet University Press.

MEB Özel Eğitim ve Rehberlik Hizmetleri Genel Müdürlüğü (2012). Özel Eğitim Hizmetleri Yönetmeliği. Ankara.

MEB Özel Eğitim ve Rehberlik Hizmetleri Genel Müdürlüğü (2015). İşitme engelliler için öğretmen klavuzu. Ankara.

Milli Eğitim Bakanlığ1 (MEB) (2010). Ortaoğretim geometri dersi 9-10. sınıflar öğretim program1. Ankara.

NCTM, (2000). Principles and standards for school mathematics. Reston, VA: Author. 
Marschark, M., and Hauser, P. C. (2012). How deaf children learn, what parents and teachers need to know. New York, NY: Oxford University Press.

Swanwick, R., Oddy, A., and Roper, T. (2005). Mathematics and deaf children: An exploration of barriers to success. Deafness and Education International, 7, 1-11. https:/ / doi.org/10.1179/146431505790560446

Tanrıdiler, A. (2013). İşitme engelli öğrencilerle yapılan matematik öğretimi araştırmalar1. e-Journal of New World Sciences Academy-Education Sciences, 8, (1), 146-163.

Tanridiler, A., Uzuner, Y., and Girgin, U. (2015). Teaching and learning mathematics with hearing impaired students. The Anthropologist, 22(2), 237-248. https:/ / doi.org/10.1080/09720073.2015.11891874

Tüfekçioğlu, Ü. (1998). İşitme engelliler. (ss.105-124). S. Eripek (Ed.), Özel eğitim, Eskişehir: Anadolu Üniversitesi Açıköğretim Fakültesi Yayınları.

Usiskin, Z. (1982). van Hiele levels and achievement in secondary school geometry. Chicago: University of Chicago. ERIC Document Reproduction Service No. ED 220288.

van De Walle, J.A., Karp, K.S. and Bay-Williams, J.M. (2013). Illkokul ve ortaokul matematiği: gelişimsel yaklaşımla öğretim. (S. Durmuş, Çev. Ed.) Ankara: Nobel.

Yıldırım, A. (2009). Euclidean reality geometri etkinliklerinin, işitme durumuna göre ögrencilerin van Hiele geometri düzeylerine, geometri tutumlarna ve başarılarma etkisi. (Yayınlanmamış Yüksek Lisans Tezi). Osmangazi Üniversitesi, Fen Bilimleri Enstitüsü, Eskişehir.

\section{Summary}

\section{Introduction}

Hearing is one of the senses that are used effectively both in daily life and education. Hearing impairment negatively affects the linguistic, mental and social development of students. Hearing-impaired students are different from normally hearing students. Hearing impairment affects learning processes (Girgin, 2003; Tüfekçioğlu, 1998). In order to design a suitable learning environment, determining the current learning of the students with hearing impairment is important. In this study, geometric understanding of students with hearing impairment was investigated according to the van Hiele's Geometric Thinking. For this purpose, the geometric thinking levels of students with hearing impairment were examined.

Not many studies have been conducted with students with hearing impairment in mathematics education. In particular, very little study has been done on teaching geometry. Only one study (Yildırım, 2009) compared the van Hiele geometric thinking levels of students with hearing impairment at the eighth grade level before and after the education. As can be seen, it is a gap in the literature to determine the van Hiele geometric thinking levels of students with hearing impairment in secondary school and to reveal in detail that how they change according to different variables. In this context, this study examined how the van Hiele geometric thinking levels of hearing impaired students in secondary school were distributed according to gender, class level, type of primary school they graduated from, having hearing impaired person in the family, using hearing assistive technology, receiving support in terms of education and sign language level. 


\section{Method}

In this study, the geometric thinking levels of 5th, 6th, 7th and 8th grade students with hearing impairment were investigated. The model of this study is cross-sectional survey, since the description was carried out instantaneously and once by determining the situation. The data of the study were collected from 126 students with hearing impairment in Ankara, Kirıkkale, Konya and Niğde in the Central Anatolia Region. The van Hiele Geometric Thinking Levels Test was used to determine the geometric thinking levels of students with hearing impairment. This test, developed by Usiskin (1982), was adapted to Turkish by Duatepe (2000) and validity-reliability studies were carried out. A demographic information form was also used to obtain information about the students in the study group such as gender, class level, family members with hearing impairment, use of hearing aid technology, support education and sign language level.

\section{Results}

According to the result, $78.1 \%$ of female students with hearing impairment were at level 0 . While $21.9 \%$ of the female students were at the visualization level, there was no female student at the analysis level. On the other hand, $67.7 \%$ of male students with hearing impairment were assigned to level 0 . While $27.4 \%$ of male students were at the visualization level, $4.8 \%$ of male students were at the analysis level.

It was observed that $54.2 \%$ of the 5 th grade students with hearing impairment were assigned to level 0 . On the other hand, $41.7 \%$ of 5 th grade students were at the visualization level and $4.2 \%$ at the analysis level. While $96 \%$ of 6 th grade students were at level $0,4 \%$ of them were at the visualization level. A striking finding was that there is no 6th grade student at the analysis level. $69.4 \%$ of 7 th grade students were assigned to level $0.27 .8 \%$ of these students were at the visualization level and $2.8 \%$ at the analysis level. $73.2 \%$ of 8 th grade students were at level $0,24.4 \%$ at visualization level and $2.4 \%$ at analysis level.

While $46.7 \%$ of the students who have completed their primary school education in normal primary schools were assigned to level $0,53.3 \%$ are at the visualization level. No students who graduated from normal primary schools could be assigned to the analysis level. $76.6 \%$ of the students who completed their primary school education in primary schools for the hearing impaired were assigned to level 0. $20.7 \%$ of these students were at the visualization level and $2.7 \%$ at the analysis level.

It was observed that $75 \%$ of the students who stated that they were hearing impaired people other than themselves in their family were assigned to level $0.23 .3 \%$ of these students were at the visualization level and $1.7 \%$ at the analysis level. $71.2 \%$ of the students who stated that they had no hearing impaired family member other than themselves in their family were at level $0.25 .8 \%$ of the same students were at the visualization level and $3 \%$ at the analysis level.

\section{Discussion}

When the distribution of geometric thinking levels of middle school students with hearing impairment by gender was examined, there was a situation in favor of male students, although there was not much difference between them. In a study conducted by Fidan and Türnüklü (2010) with fifth grade students with normal hearing, it was found that the geometric thinking levels of female students were higher than that of 
male students. The van Hiele geometric thinking levels were revealed by the researchers according to the grade levels of the students with normal hearing. According to the National Council of Teachers of Mathematics (NCTM), students are expected to be at the visualization level until the third grade, the analysis level from the third grade to the sixth grade, and at the informal deduction level from the sixth to the ninth grade (NCTM, 2000). Similarly, van De Walle et al. (2012) stated that up to the eighth grade students can be at visualization, analysis and informal deduction levels. On the other hand, Baykul (2009) stated that students can be at the level of visualization and analysis up to the sixth grade and at the informal deduction level from the sixth to the ninth grade. Clements and Battista (1992) stated that preschool students' geometric thinking skills may be at the pre-recognition level before the visualization level. When these geometric thinking levels expected for normally hearing students in the literature are compared with the results obtained in this study, it can be said that the geometric thinking levels of middle school students with hearing impairment are lower than normal students.

\section{Pedagogical Implications}

It is thought that there are many different reasons behind the lower than expected the van Hiele geometric thinking levels of middle school students with hearing impairment. It is not correct to think that the low geometric thinking levels of the students with hearing impairment are only due to hearing loss. It can be said that if geometry lessons are taught in suitable learning environments and in sufficient time for students with hearing impairment, their understanding of geometry and reasoning skills can improve.

\section{Araştırmanın Etik Taahhüt Metni}

Yapılan bu çalışmada bilimsel, etik ve alıntı kurallarına uyulduğu; toplanan veriler üzerinde herhangi bir tahrifatın yapılmadığı, karşılaşılacak tüm etik ihlallerde "Cumhuriyet Uluslararası Eğitim Dergisi ve Editörünün" hiçbir sorumluluğunun olmadığı, tüm sorumluluğun Sorumlu Yazara ait olduğu ve bu çalışmanın herhangi başka bir akademik yayın ortamına değerlendirme için gönderilmemiş olduğu sorumlu yazar tarafından taahhüt edilmiştir.

\section{Yazar Bilgileri/Authors' Biodata}

Nurullah ŞİMŞEK, lisans eğitimini Selçuk Üniversitesi Eğitim Fakültesi matematik öğretmenliği bölümünde tamamlamıştır. Yüksek Lisans ve doktorasını Gazi Üniversitesi Eğitim Bilimleri Enstitüsü matematik eğitimi alanında yapmıştır. Halen Kırıkkale Üniversitesi Eğitim Fakültesinde Dr. Öğr. Üyesi olarak görev yapmaktadır.

Nurullah Şimşek is Assist. Prof. Dr. in Faculty of Education at Kırıkkale University. He received his BA in department of mathematics education at Selçuk University, MA and $\mathrm{PhD}$ in the field of mathematics education at Gazi University, Turkey.

Kenan ÇAĞLIYAN, lisans eğitimini Gazi Üniversitesi Eğitim Fakültesi İlköğretim Matematik Öğretmenliği bölümünde tamamlamıştır. Yüksek lisans eğitimini Gazi Üniversitesi Eğitim Bilimleri Enstitüsünde matematik eğitimi alanında yapmıştır. Halen Milli Ĕ̆itim Bakanlığında öğretmen olarak görev yapmaktadır. 
Kenan Çağlıyan completed his BA at Gazi University, Faculty of Education, department of Elementary Mathematics Education. He received his MA degree in the field of mathematics education at Gazi University, Turkey. He is still working as a teacher at the Ministry of Education. 